\section{Effects of TCAP on water intake in the rat ${ }^{1}$}

EDWARD M. GUROWITZ, C. W. Post College, Long Island University, Greenvale, N.Y. 11548

The drug, TCAP, which has been shown to enhance brain nucleoprotein production, has also been reported to enhance performance in learning tasks. Water intake of 10 rats was measured for 4 days without injection and over 4 days of daily injections of $45 \mathrm{mg} / \mathrm{kg}$ of TCAP. A transitory increase $(p<.01)$ in water intake was found for the period after 30 min postinjection, but there was no overall increase over the 24-h period. In addition, day-to-day variability in water intake was increased $(p<.05)$ during the drug days. Studies of the drug, using water motivation, should take this effect into account.

The drug, TCAP, 2 has been linked to the nucleic-acid and nucleoprotein metabolism of the brain (Egyházi \& Hydén, 1961) and has also been proposed as a possible memory-facilitating drug (see Gurowitz, 1969). The major effects of the drug on memory appear to come about after a rather lengthy regime of daily injections. The main effect of acute administration seems to be a mild stimulant effect (Gurowitz, Gross, \& George, 1968). One effect of the drug that has not been extensively studied is the possible relation of a TCAP regimen to the motivational status of the animal. The present study represents a preliminary investigation of the effects of the drug on thirst and was suggested by earlier observation in this laboratory (Gurowitz et al, 1968) on the behavior of TCAP-treated Ss on a water-motivated passive avoidance task.

\section{SUBJECTS}

The Ss were 10 naive adult male albino rats of the Holtzman Sprague-Dawley strain. All were 100 to 120 days old at the start of the experiment.

\section{APPARATUS AND PROCEDURE}

All Ss were housed in individual home cages, $10 \times 6 \times 10 \mathrm{in}$. They were provided with dry food and with water on an ad lib basis. After the Ss had been in the laboratory for 2 weeks, measures of water intake were begun. Each day for 4 days water bottles were removed, weighed, and replaced at 2 p.m., 2:30 p.m., and $2: 45$ p.m. After 4 days of this procedure, all Ss were injected intraperitoneally (on the 5 th day) with $45 \mathrm{mg} / \mathrm{kg}$ of TCAP in a $10-\mathrm{mg} / \mathrm{cc}$ saline solution. Injections were administered at 2 p.m., and measures of water intake were begun at 2:30 p.m. that day, on the same schedule as previously used. Thus, there was a total of 4 days of injections and three measures per day-one at $30 \mathrm{~min}$ after injection, one at $45 \mathrm{~min}$ after injection, and one at $24 \mathrm{~h}$ after injection.

Analyses were performed to compare the preinjection and postinjection scores on each measure- $30 \mathrm{~min}, 45 \mathrm{~min}$, and $24 \mathrm{~h}$. In addition, since most of the previous work on this drug has involved running animals from 30 to $45 \mathrm{~min}$ after injection, an analysis was performed on the amount drunk during this period. Mean amounts ingested for each period are shown in Fig. 1.

Analysis of the differences in water intake between the drugged and the undrugged state indicated a significant increase in water intake over the $45-\mathrm{min}$ postinjection period $(F=14.37, \mathrm{df}=1 / 19$, $\mathrm{p}<.01$ ), but this increase disappeared by the end of the $24 \mathrm{~h}$ period. Since there was no significant increase at the end of $30 \mathrm{~min}$, it would appear that the major portion of this difference is accounted for by increased drinking in the period after $30 \mathrm{~min}$ postinjection. This is reflected in the significant increase in ingestion during the 30 to $45-\mathrm{min}$ period in the drugged state $(F=12.34, \quad$ df $=1 / 19, \quad p<.01)$ Although there were significant differences on these measures over the 4 drugged days (for $45 \mathrm{~min}: \mathrm{F}=5.69$, df $=4 / 36, \mathrm{p}<.01$; for $45.30 \mathrm{~min}: \quad F=2.98, \quad \mathrm{df}=3 / 27$, $\mathrm{p}<.05$ ), this was apparently due to great day-to-day fluctuations in amount drunk. It is interesting to note, however, that the trend over the 4 days is toward an overall increase in water intake.

\section{DISCUSSION}

These preliminary data indicate that injections of TCAP may cause a transitory increase in water intake for some time following the injection. The mechanism for this increase is not clear, but the relatively small volume of material injected would seem to rule out any simple hypothesis based on the injection of a hypertonic solution.

Because most of the current work with TCAP involves long-term administration, the question of adaptation is a relevant one. Over the brief 4-day period of this study, there seems to be little adaptation, and, indeed, the trend of the great day-to-day fluctuation seems to be toward an increase. It is also instructive to note that the day-to-day variability in water intake is greater under the drug for the

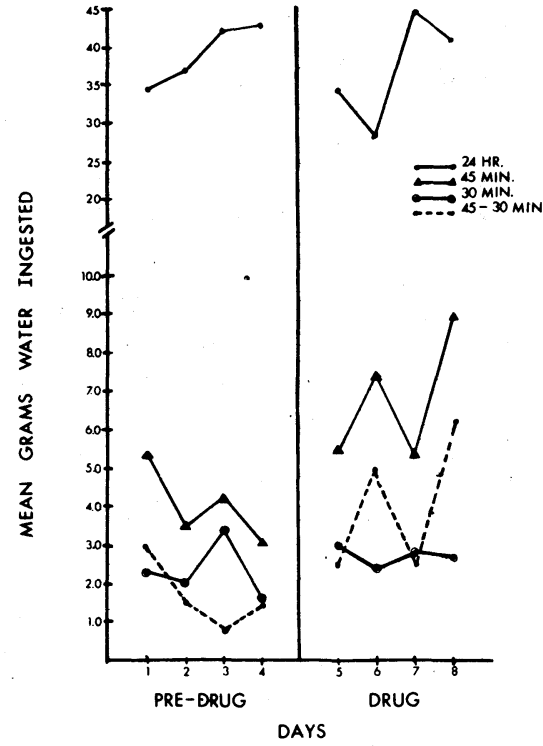

Fig. 1. Mean amounts of water ingested over the periods of measurement on each day.

24-h and 45-min measures but not for the $30-\mathrm{min}$. This may indicate a transitory illness or malaise in the Ss following injection, after which water intake increases. Observation of the Ss failed to indicate any gross abnormalities of behavior during the 30 -min period.

It is clear from these data that studies of TCAP and learning, using thirst motivation, must take into account the possible change in performance due to increased drive caused by the drug. Whether or not this effect remains important for chronic administration studies remains to be seen, but these preliminary data indicate that caution should be excercised

\section{REFERENCES}

EGYHÁZI, E., \& HYDÉN, H. Experimentally induced changes in the base composition of the ribonucleic acids of isolated nerve cells and the ir oligodendroglial cells. Journal of Biophysiology \& Biochemical Cytology, 1961, $10,403-410$.

GUROWITZ, E. M. Molecular basis of memory. Englewood Cliffs, N.J.: Prentice-Hall, 1969.

GUROWITZ, E. M., GROSS, D. A., \& GEORGE $R$. Effects of TCAP on passive avoidance in the rat. Psychonomic Science, 1968, 12, 293-294. NOTES

1. This study was supported in part by USPHS Grant No. STIMH 8396 while the author was at the University of Illinois College of Medicine. I gratefully acknowledge the aid of Robert George in taking measures and the help of Lynda Parker for preparing the figure.

2. A dimer of malononitrile characterized chemically as 1, 1, 3, tricyano-2-amino-1-propene (Upjohn U-9189). I am indebted to Dr. John Correll of the Upjohn Co. for the kind donation of a saline-soluble preparation of the drug. 